\title{
COVID-19 Tanısı ile Takipliyken Akut Mukormikoz Gelișen İki Olgu
}

\section{Two Cases of Acute Mucormycosis When Followed with the Diagnosis of COVID-19}

\author{
Mustafa Serhat ȘAHINOG̃LU'(IDD), Harun GÜR²(IID), Fatma Özlem KANDEMIR'(IID), Cengiz ÖZCAN²(IDD) \\ ${ }^{1}$ Mersin Üniversitesi Tıp Fakültesi, İnfeksiyon Hastalıkları ve Klinik Mikrobiyoloji Anabilim Dalı, Mersin, Türkiye \\ ${ }^{2}$ Mersin Üniversitesi Tıp Fakültesi, Kulak Burun Bog̃az Hastalıkları Anabilim Dalı, Mersin, Türkiye
}

Makale atıfi: Şahinoğlu MS, Gür H, Kandemir FÖ, Özcan C. COVID-19 tanısı ile takipliyken akut mukormikoz gelişen iki olgu. FLORA 2021;26(3):5505.

\begin{abstract}
ÖZ
Koronavirüs hastalığı 2019 (COVID-19), Mart 2020'den beri devam eden bir pandemiye neden olmaktadır. Başta diyabetes mellitus (DM) olmak üzere kronik hastalığı olanların komplikasyonlar ve mortalite açısından yüksek risk altında olduğu gösterilmiştir. Mukormikoz nadir görülmesine karşı invaziv ve fulminan seyirli bir hastalıktır. COVID-19 ve invaziv aspergilloz birlikteliğiyle ilişkili literatürde birçok çalışma olmasına rağmen, COVID-19 ve mukormikozla ilgili az sayıda olgu raporları mevcuttur. Bu yazımızda DM hastası olan ve COVID-19 tanısı konulmuş iki akut rino-orbital-serebral mukormikoz olgusu sunulmuştur. Mukormikozun erken tanı ve tedavisi, morbidite ve mortaliteyi azaltmada önemlidir.
\end{abstract}

Anahtar Kelimeler: COVID-19; Diyabetes mellitus; Mukormikoz

\section{ABSTRACT}

\section{Two Cases of Acute Mucormycosis When Followed with the Diagnosis of COVID-19}

\author{
Mustafa Serhat ȘAHINOG̃LU', Harun GÜR², Fatma Özlem KANDEMIR', Cengiz ÖZCAN²
}

\footnotetext{
${ }^{1}$ Department of Infectious Diseases and Clinical Microbiology, Mersin University Faculty of Medicine, Mersin, Turkey

2 Department of Otolaryngology, Mersin University Faculty of Medicine, Mersin, Turkey
}

Coronavirus disease 2019 (COVID-19) has caused an on-going pandemic since March 2020. It has been shown with clinical studies that patients with chronic illnesses, notably diabetes mellitus, are under high risk of complications including death. Mucormycosis is invasive and fulminant even though it is rare. Although there are numerous studies existing in the literature about COVID-19 cases with invasive Aspergillosis, there are a couple of studies reported about COVID-19 cases with mucormycosis. In this study, it was aimed to present two cases of COVID-19 with diabetes and acute rhino-orbital-cerebral mucormycosis. Early diagnosis and treatment of mucormycosis is crucial to decrease morbidity and mortality.

Key Words: COVID-19; Diabetes mellitus; Mucormycosis

Geliș Tarihi/Received: 24/02/2021- Kabul Ediliș Tarihi/Accepted: 12/05/2021 


\section{GiRiș}

Siddetli akut solunum sendromu Koronavirüs 2 (SARS-CoV-2)'nin neden olduğu Koronavirüs hastalığı 2019 (COVID-19) 11 Mart 2020'de Dünya Sağlık Örguitui tarafından pandemi olarak ilan edilmiștir. 5 Subat 2021 tarihi itibarıla dünyada 105 milyonun üzerinde doğrulanmıs vaka saptanmıs olup, iki milyonun üzerinde COVID-19 ile ilișkili ölüm gerçekleșmiștir.

Kronik hastalık veya immünsüpresyon varlığı SARS-CoV-2 ile infekte olma riskini arttırabileceği gibi, infekte hastalarda da hastalığın seyrini önemli derecede etkileyerek daha yüksek komplikasyon ve mortalite riski olușturmaktadır. Dünyadaki sıklığ1 2019 yılında \%9.3 olarak bildirilen diyabetes mellitus (DM) önemli bir kronik hastalıktır ve COVID-19 ile arasındaki ilișki cift yönlüdür. SARS-CoV-2 infeksiyonu diyabetiklerde daha ağır seyretmekte, glisemik kontrolü bozmakta, diyabet hastalığı ise SARS-CoV-2 kliniğini ağırlaștırmaktadir.

Mukormikoz, nadir görülen ancak invaziv ve fulminan seyirli bir sistemik mantar infeksiyonudur. Özellikle kontrol altına alınamamıs diyabet, hematolojik maligniteler, uzun süreli immünsüpresif tedavi veya kortikosteroid tedavisi bașlica predispozan faktörlerdir.

Bu yazıda COVID-19 tanısı konulmus, DM'li iki olguda gelisen akut rinoorbital serebral mukormikoz infeksiyonu sunulmuștur.

\section{OLGU SUNUMU}

\section{Olgu 1}

Kırk beș yașında erkek hasta, ateș yüksekliği sikayetiyle ikinci basamak sağlık kurulușuna bașvurmus. Nazofarengeal sürüntü örneğinde SARS CoV-2 PCR testinin pozitif saptanması üzerine favipiravir, coraspin ve levofloksasin tedavisi düzenlenerek evde takibi önerilmiș. Tanı konulduktan bşe gün sonra hastada nefes darlığı gelișmesi üzerine, diș merkezde yatıșı yapılmıș. Bașurusunda genel durumu orta, oksijen saturasyonu $\left(\mathrm{SpO}_{2}\right)$ \%89, nabız 110/dk ve tansiyon: 120/90 mmHg olarak kaydedilmiștir. Bașvuru anında kan

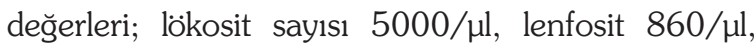
CRP $5.5 \mathrm{mg} / \mathrm{dl}$ (0-0.8), prokalsitonin $0.13 \mathrm{ng} / \mathrm{ml}$ (0-0.5), ferritin $513 \mathrm{ng} / \mathrm{ml}$ ve glukoz $181 \mathrm{mg} /$ dl saptanmıștır. Akciğer bilgisayarlı tomografisinde

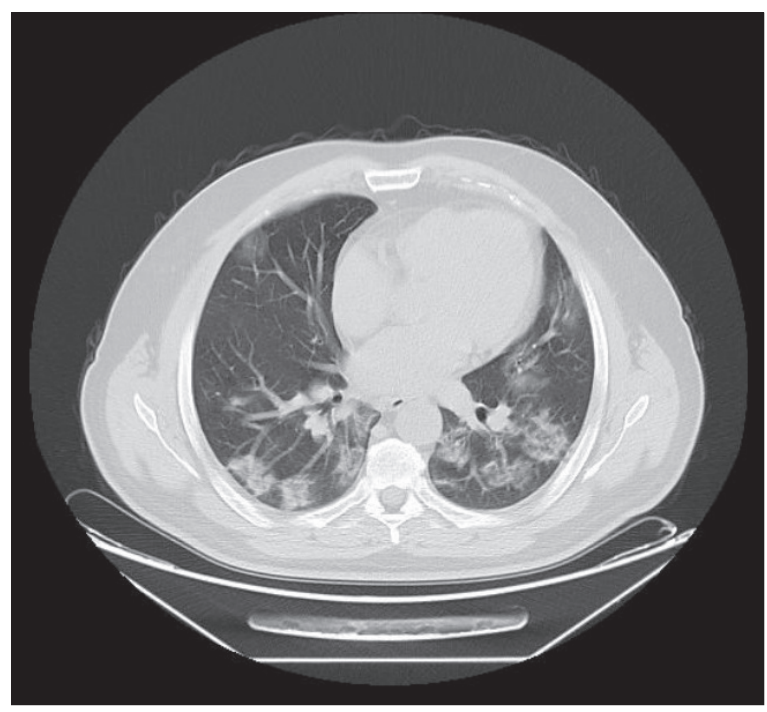

Resim 1. Akciğer BT: Her iki akciğerde periferik konsolidasyon ve buzlu cam dansitesi.

(BT), her iki akciğerde periferik konsolidasyon ve buzlu cam dansitesi mevcut olup, viral pnömoninin orta siddette tutulumuyla uyumlu olarak raporlanmıștır (Resim 1).

Hastanın tedavisi piperasilin tazobaktam $3 \times 4.5$ g, klaritromisin 2x500 mg, hidroksiklorokin 2x200 $\mathrm{mg}$, enoksaparin sodyum $1 \times 0.6 \mathrm{ml}$ ve metilprednisolon 1x40 mg olarak düzenlenmiș. Bu tedaviyle hastanın solunum sikayetleri gerilemis, oda havasında $(\mathrm{OH})$ takip edilmeye başlanmıș ve takiplerinde $\mathrm{SpO}_{2}(\mathrm{OH}) \% 93$ ve üzerinde olarak izlenmiș. Yatıșının 10. gününde sol gözde ağrı, yüzde uyușma șikayetleri gelișmiștir. Yapılan muayenede her iki gözde blefarit, sol göz kapağında total pitozis, solda laterale bakıș paralizisi, süperiora ve inferiora bakıșta hafif kısıtllik tespit edilmiștir. Yüzün sol tarafında uyușukluk hissi olan hastanın muayenesinde fasyal paralizi saptanmamıștır. U̇çüncü ve altıncı kranial sinir paralizisi mevcuttur. Maksillofasyal, orbital ve serebral BT ve manyetik rezonans (MR) görüntüleme, "Sol maksiller bölgede cilt, cilt altı yağ planları heterojen görünümde, sol ethmoid sinüste yumuşak doku dansiteleri izlenmektedir. Solda propitozis görünümü mevcuttur. Periorbital ve retroorbital yağlı planlar heterojen görünümdedir." seklinde raporlanmıștır (Resim 2). Mevcut radyolojik ve klinik durumla periorbital selülit olarak değerlendirilmiș ve üçüncü basamak sağlık kuruluşu olarak tarafımıza sevk edilmiștir. Merkezimize yatıșı yaplan hastanın takiplerinde 


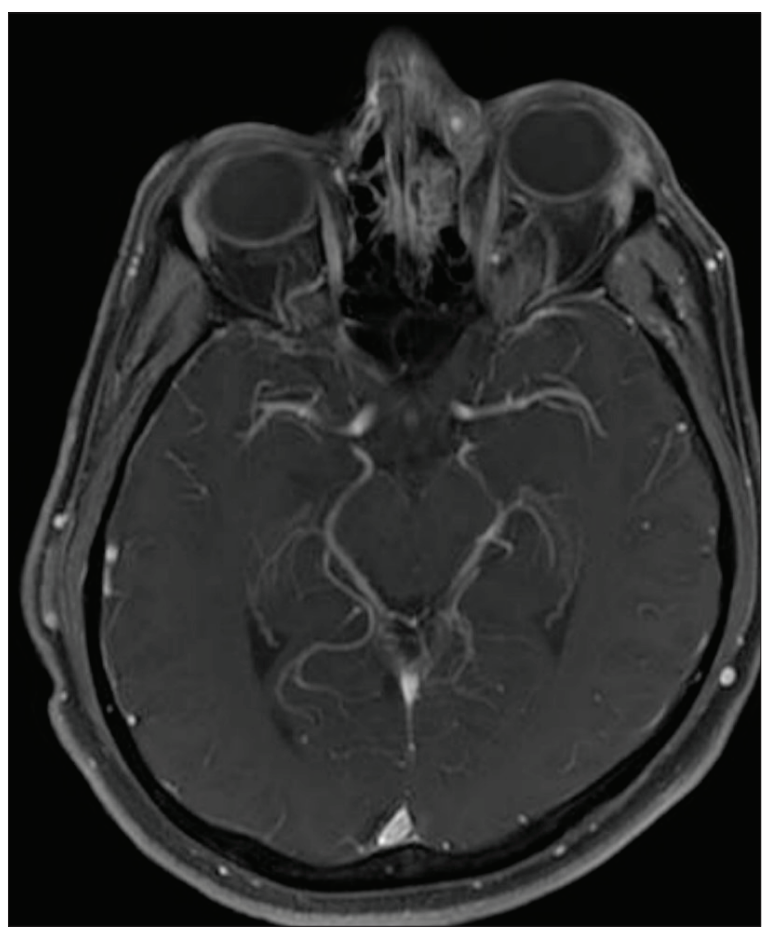

Resim 2. Kontrastlı serebral MR, yağ baskılı T1 ağırlıklı aksiyel kesit: Sol maksiller bölge cilt, cilt altı heterojen görünümde, sol ethmoid sinüste yumuşak doku dansiteleri mevcut, periorbital ve retroorbital yağlı planlarda heterojen görünüm.

kan sekeri yüksek izlendi. HbA1C değeri 10.2 olan hastaya DM tanısı konularak insülin tedavisi bașlandi. Mukormikoz ön tanisıyla liposomal amfoterisin B $5 \mathrm{mg} / \mathrm{kg} /$ gün olarak bașlandı. Orbita dekompresyonu yapılan hastanın doku kültüründeki üreme, Mucor spp. olarak raporlandı. Histopatoloji örneğinin periyodik asit schiff reaksiyonu (PAS) ve Grocott's Methenamin Silver (GMs) boyaması sonucunda fungal hifa yapları izlendi ve patoloji sonucu doku ve damar invazyonu olan mukormikoz olarak raporland. Tedaviye ve orbita dekompresyonuna rağmen klinik iyileșme görülmeyen hastaya bir hafta sonra orbita ekzanterasyonu yapild. Alt1 haftası ameliyat sonrası olmak üzere totalde sekiz haftadir liposomal amfoterisin B tedavisi alan hastanın genel durumunda iyileșme ve lezyonlarında gerileme saptand. Hastanın hastanede tedavisine halen devam edilmektedir.

\section{Olgu 2}

Yetmiș iki yașında kadın hasta, nefes darlığ1 sikayetiyle ikinci basamak sağllk kurulușuna bașvurmustur. Öz geçmișinde DM, hipertansiyon $(\mathrm{HT})$, konjestif kalp yetersizliği (KKY) ve koroner

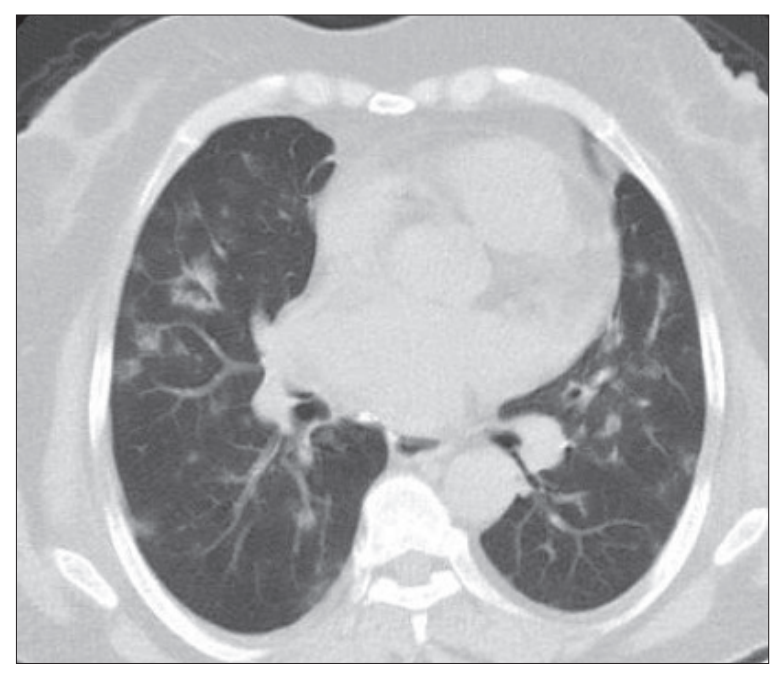

Resim 3. Akciğer BT: Her iki akciğerde, çoğunluğu periferik yerleşimli, yer yer birleşme eğiliminde, yamalı buzlu cam dansiteleri.

arter hastalığı (KAH) mevcutmuș. On yıldır DM tanısı varmıs ve iki yıldır oral antidiyabetik ilac (OAD) kullanmaktadir.

Genel durumu iyi, bilinci açık, ates yüksekliği olmayan hastanın $\mathrm{SpO}_{2}(\mathrm{OH}) \% 88$, nazal kanülden 2 lt $\mathrm{O}_{2}$ tedavisiyle $\mathrm{SpO}_{2}$ \%98'dir. Bassvuru

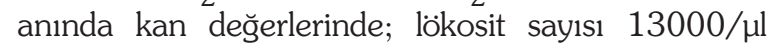
lenfosit: 2190/ $\mathrm{ll}$, CRP $4 \mathrm{mg} / \mathrm{l}$, ferritin $25 \mathrm{ng} /$ ml ve glukoz $101 \mathrm{mg} / \mathrm{dl}$ ve $\mathrm{HbA} 1 \mathrm{c} 6.2$ saptanmıștır. Akciğer BT'sinde her iki akciğer üst ve alt loblarda, coğunluğu periferik yerleșimli, yer yer birleșme eğiliminde, yamalı buzlu cam dansiteleri mevcutmus ve hafif dereceli COVID-19 pnömonisi ile uyumlu olarak raporlanmıștır (Resim 3).

Hasta COVID-19 pnömonisi ön tanısıyla, bașvurduğu dıs merkez hastanede yatırılmıstır. Nazofarengeal sürüntü örneği SARS-CoV-2 PCR testi pozitif olarak sonuçlanmıștır. Favipiravir, moksifloksasin $1 \times 400 \mathrm{mg}$, enoksaparin sodyum $1 \times 0.6$ $\mathrm{ml}$ ve metilprednisolon $1 \times 40 \mathrm{mg}$ bașlanmıștır. Yatıșının dördüncü gününde kan sekerlerinin yüksek olması nedeniyle insülin tedavisine gecilmistir. Favipiravir tedavisi beșinci gün sonunda kesilmiștir. Yatıșının yedinci gününde geniz akıntısı, ağız içinde yara, baș ağrısı sikayetleri gelișmiștir. Serebral MR bulguları akut sinüzitle uyumlu olarak raporlanmıstır. Hastaya akut maksiler sinüzit tanısıyla, moksifloksasin tedavisi kesilerek meropenem ve metronidazol tedavisi bașlanmıstır. Tedaviye rağmen sikayetleri gerilemeyen ve sol gözde ağrı 


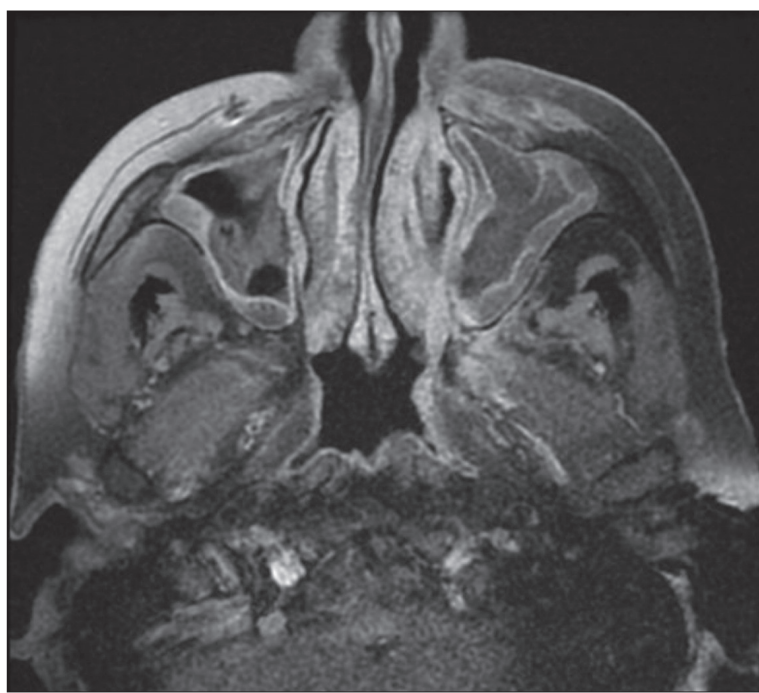

Resim 4. Kontrastlı serebral MR, yağ baskılı T1 ağırlıklı aksiyel kesit: Sol orbitaya, sol ekstraoküler kaslara, solda preseptal ve premaksiller alana uzanım gösteren inflamatuvar değişiklikler.

sikayeti gelișen hastanın muayenesinde pitozis, ekzoftalmi, kemozis ve göz hareketlerinde yaygın kıstlanma tespit edilmistir. Sol gözde kornea ve 1șık refleksi alınamamıstır. Üc hafta sonra tekrarlanan orbita ve serebral MR sonucu "Sol orbitaya, sol ekstraoküler kaslara, solda preseptal ve premaksiller alana uzanım gösteren inflamatuvar değisiklikler izlenmistir. Ayrıca suprasellar sisterna ve solda pontoserebellar köșe sisternasının da tutulduğu saptanmıștır; solda kavernöz sinüste de yaygın inflamatuvar değisiklikler izlenmiștir." seklinde raporlanmıștır (Resim 4). Hasta dıs merkezden tarafımıza sevk edilmistir. Hastanın mevcut durumu pansinüzit ve orbital selülit ile uyumluydu ve radyolojik açıdan mukormikoz açısından süpheliydi. Ayrıca radyolojik görüntülemede sol internal karotis arter içerisinde septik trombüs ile uyumlu görünüm mevcuttu. Hastaya linezolid 2x600 mg ve meropenem $3 \times 1 \mathrm{~g}$ olarak antibiyoterapi bas land. Fonksiyonel endoskopik sinüs cerrahisi ve orbita dekompresyonu yapıld. Alınan doku ve apse kültüründe üreme olmadı ancak histopatolojik incelemede PAS ve GMs boyama ile fungus spor ve hifaları görüldü. Patoloji örneği doku invazyonu olan ancak damar invazyonu olmayan mukormikoz olarak raporlandi. Hastanın mevcut tedavisine ilave olarak liposomal amfoterisin B 10 $\mathrm{mg} / \mathrm{kg} /$ gün olarak bașlandi. Antifungal tedavinin altıncı haftasında olup hastanın mevcut tedavileri ve takiplerine halen devam edilmektedir.

\section{TARTIȘMA}

Mukormikoz, Zygomycetes sinifinın Mucorales takımında bulunan patojenlerin neden olduğu infeksiyonları tanımlar. Mukormikozun bașlica nedeni olarak en sik bildirilen patojenler Rhizopus spp, Mucor spp. ve Lichtheimia spp. (eski adı Absidia ve Mycocladus)'dir ${ }^{[1,2]}$. Mukormikozun en yaygın klinik görünümü, duyarlı bir konağın paranazal sinüslerine fungus sporlarının inhalasyonuna sekonder gelisen rino-orbital-serebral infeksiyondur ${ }^{[3]}$.

Tanımlamada ve raporlamadaki cesitli zorluklar nedeniyle mukormikozun insidansını ve prevalansinı belirlemek zordur. Bununla beraber orbital tutulumu mevcut akut invaziv rino-orbital-serebral mukor prevalansının Amerika Birlesik Devletleri'nde milyonda 1.7 olduğu tahmin edilmektedir ${ }^{[4]}$. Mukormikozun mortalite oranları, komorbiditelere ve infeksiyon bölgesine bağlı olarak \%40 ila 80 arasında değișmektedir ${ }^{[1,5]}$. Merkezi sinir sistemiyle birlikte olan yaygin hastalık durumunda, mortalite genellikle \%80'nin üzerine clkmaktadır ${ }^{[1]}$.

DM, malignite, immünosupresif veya kortikosteroid tedavi, organ ve hematopoetik kök hücre transplantasyonları hastalık gelișimi için bașlıca predispozan faktörlerdir. Bunlar arasında sıklığı en fazla olan predispozan faktör (\%60-80) diyabettir ${ }^{[6,7]}$.

Kronik hastalıklar ve diğer komorbiditeler, SARS-CoV-2 ile infekte hastalarda da hastalığın seyrini etkileyip komplikasyon ve mortalite riskini arttırmaktadır.

Sekiz çalıșmayı ve 46.248 COVID-19 hastas1$\mathrm{n} 1$ içeren bir meta-analizde diyabet prevalansı \%8 olarak bildirilmiștir ve bu COVID-19 hastalarında en sık gözlenen ikinci komorbiditedir ${ }^{[8]}$.

Kronik diyabet zemininde olușan doğal immün cevabın disregülasyonu, endotel disfonksiyonu ve bozulmus bariyer yapisiyla proinflamatuvar hiperkoagülabite durumu, COVID-19 infeksiyonunun klinik seyrinin ağırlașmasına neden olabilecek olası mekanizmalardır ${ }^{[9]}$.

Yapılan bir calıșmada DM'li COVID-19 hastalarının yalnızca daha siddetli pnömoni riski tașımadığı, aynı zamanda artmıs inflamatuvar biyobelirteçlere de sahip olduğu gösterilmiștir ${ }^{[10]}$.

COVID-19 ile DM arasındaki iliski cift yönlüdür. SARS CoV-2 infeksiyonu, diyabetiklerde 
glisemik kontroliu bozmakta, diyabet ise SARSCoV-2 kliniğini ağırlaștırmaktadır. $\mathrm{Bu}$ nedenle diyabetli bireylerin COVID-19 hastaları arasında ölüm dahil olmak üzere komplikasyonlar acısından yüksek risk altında olduğu belirtilmektedir ${ }^{[11]}$

Ayrıca özellikle solunum desteği ihtiyacı olan siddetli COVID-19 infeksiyonunun tedavisinde rol oynayan kortikosteroidler, akciğer inflamasyonunu baskılamakla birlikte bağıșıklığı ve patojen klirensini de inhibe ederler. Kortikosteroidlerin glisemik kontrolü kötüleștirdiği, psikoz ve avasküler nekroz dahil olmak üzere mortalite ve komplikasyonları arttırdığı bildirilmiștir ${ }^{[12]}$.

COVID-19 ile fungal infeksiyon birlikteliğini bildiren makale sayısı azdır. Bunlar da genellikle invaziv pulmoner aspergilloz gelișimiyle ilgili çalıșmalardir ${ }^{[11,13]}$.

Literatürde 2003'teki SARS deneyimine ve birlikte görülen invaziv aspergilloz vakalarına dayanarak, fungal infeksiyonların eșlik ettiği COVID-19 olasılığına dikkat etmek gerektiği vurgulanmakta$\operatorname{dir}^{[14]}$.

COVID-19'un sekonder fungal infeksiyonlara zemin hazırlayan spesifik patofizyolojik özellikleri vardır. Bunlar; yaygın pulmoner hastalığa neden olma eğilimi ve buna bağlı alveolo-interstisyel patoloji ile birlikte düșük $\mathrm{CD} 4+\mathrm{T}$ ve $\mathrm{CD} 8+\mathrm{T}$ hücresi ile ilișkili immün hasarın doğal bağıșıklığı bozmasıdır ${ }^{[15]}$. COVID-19'un neden olduğu muhtemel immün düzensizlik nedeniyle hem bakteriyel hem de fungal ikincil infeksiyonların insidansında artış olabileceği, ayrıca COVID-19'a karșı tedavinin bir parçası olarak yaygın kullanılan steroidlerin/monoklonal antikorların/geniș spektrumlu antibiyotiklerin fungal infeksiyonların gelișmesine/ siddetlenmesine yol açabileceği bildirilmiștir ${ }^{[16]}$.

"Mucor" ve "COVID-19" ile ilgili makaleler için literatürü taradığımızda ise az sayıda ve sadece olgu raporları seklinde yazılara rastlanmaktadir $^{[16-18]}$.

Mukormikozda infeksiyon genellikle paranazal sinüslerden kaynaklanır, kemik destrüksiyonu sonrası orbita, göz ve beyne invazyon yapabilir. Tek taraflı yüz ödemi, proptozis, selülit ve nekroza dönüsen palatal veya palpebral fistül görülebilir. Olgularımızın ilkinde göz ağrısı yüzde uyușma, gözde bakıș kısıtlılığı ile proptozis sikayetleri mev- cutken, ikinci olgumuzda ilk sikayetler ağız içinde yara, bas ağrısı ve hemen sonrasında göz ağrısı, yüzde ödem ve bakıș kısıtlığı seklinde olmuștur.

Histopatoloji, direkt mikroskopi ve klinik örneklerden kültür, mukormikoz için bașlica tanısal yöntemlerdir ${ }^{[19]}$. Mukormikoz teshisi zordur fakat erken teshis ve tedavi prognoz açısından önemlidir. Yaplan bir calıșmada teșhis ve tedavide altıgünlük gecikme, 30 günlük mortalitenin \%35'ten \%66'ya çkmasıyla ilișkilendirilmiștir ${ }^{[20]}$. Tedavide; sistemik antifungal tedaviye ek olarak, mümkün olduğunca erken cerrahi tedavi önerilmektedir. Olgularımızdan ilkinde cerrahi esnasında alınan doku kültuiründe, Mukor spp. üremesi bildirildi ancak ikinci olgumuzda üreme olmadi. Ancak her iki hastamızın da histopatolojisi mukormikoz ile uyumlu bulundu ve hastarimiza lipozomal amfoterisin B tedavisi başland. Ayrıca her iki hastam1za orbita dekompresyonu yapildı. İlk olgumuzda progresyonun devam etmesi üzerine orbita ekzanterasyonu da yapıldı. Olgularımız halen izlem altında olup ikisinde de antifungal tedaviye devam edilmekle beraber birinci olgumuzun bulgularında iyileșme mevcut olup klinik seyri stabil olarak seyrederken, ikinci olgumuzda santral sinir sistemi tutulumu olması ve gecikmis tanı nedeniyle klinik ve radyolojik olarak hastalık progresyonu mevcuttur.

\section{SONUÇ}

Tek bașına COVID-19'un mukormikoz gelișimi üzerine kolaylaștırıcı etkisinin varlığını mevcut literatür bilgileri eșliğinde söyleyebilmek güctür. Bununla birlikte COVID-19'a bağlı immün hasarın yanı sıra, iyi kontrol edilemeyen DM varlığı, kortikosteroid kullanımı, geniș spektrumlu antibiyotik kullanımı gibi faktörlerden birkaçının bir arada bulunması mukormikoz gelișmesine neden olabilir. Bu konuda kapsamlı çalıșmalara ihtiyaç olduğu açıktır. Klinisyenler özellikle siddetli COVID-19 geçiren ve özgeçmișinde bașta DM olmak üzere kronik hastallk bulunan ya da immünsüpresif durumu olan hastalarda sekonder fungal infeksiyonlar için dikkatli olmalıdırlar. Bu tür infeksiyonlarda erken $\tan 1$ ve tedavinin morbidite ve mortaliteyi azaltacağı unutulmamalıdır.

\section{ÇIKAR ÇATIŞMASI}

Yazarlar bu makale ile ilgili herhangi bir cıkar çatısması bildirmemișlerdir. 


\section{YAZAR KATKISI}

Anafikir/Planlama: MSS

Analiz/Yorum: FÖK, HG

Veri sağlama: MSȘ, HG, CÖ

Yazım: ÖK, MSS

Gözden Geçirme ve Düzeltme: MSȘ, HG

Onaylama: FÖK

\section{KAYNAKLAR}

1. Roden MM, Zaoutis TE, Buchanan WL. Epidemiology and outcome of zygomycosis: a review of 929 reported cases. Clin Infect Dis 2005;41:634-53.

2. Skiada A, Pagano L, Groll A. Zygomycosis in Europe:analysis of 230 cases accrued by the registry of the European Confederation of Medical Mycology (ECMM) Working Group on Zygomycosis between 2005 and 2007. Clin Microbiol Infect 2011;1 7:1859-67.

3. Cox G. Mucormycosis. Up To Date, July 2020;2020.

4. Zhang J, Kim JD, Beaver HA. Rhino-orbital mucormycosis treated successfully with posaconazole without exenteration. Neuroophthalmology 2013;37:198-203.

5. Guinea J, Escribano P, Vena A. Increasing incidence of mucormycosis in a large Spanish hospital from 2007 to 2015 Epidemiology and microbiological characterization of the isolates. PLoS One 2017;12:e0179136.

6. Butugan O, Sanchez TG, Goncalez F, Venosa AR, Miniti A. Rhinocerebral mucormycosis: predisposing factors, diagnosis, therapy, complications and survival. Rev Laryngol Otol Rhinol (Bord) 1996;117(1):53-5.

7. Coșkun H, Hizalan I, Erișen L, Basut O, Heper Y, Akalın H. Rinoserebral mukormikozis: uc olgu sunumu. Türk Otolarengol Arş 2004;42(1):41-50.

8. Yang J, Zheng Y, Gou X, Pu K, Chen Z, Guo Q, et al. Prevalence of comorbiditiesin the novel Wuhan coronavirus (COVID-19) infection: a systematic review and meta-analysis. Int J Infect Dis 2020;94:91-5.

9. Türkiye Diyabet Vakfı. COVID-19 Pandemi Diyabet İlem ve Tedavi Kriterleri Uzlası Raporu.

10. Ye $Q$, Wang B, Maol. The pathogenesis and treatment of the "Cytokine Storm" in COVID-19. I Infect 2020;80(6):607. 13.
11. Yang $X, Y u Y, X u$ J. Clinical course and outcomes of critically ill patients with SARS-CoV-2 pneumonia in Wuhan, China: a single-centered, retrospective, observational study. Lancet Respir Med 2020;8(5):475e81.

12. Russell CD, Millar JE, Baillie JK. Clinical evidence does not support corticosteroid treatment for 2019-nCoV lung injury. Lancet 2020;395(10223):473-5.

13. Koehler P, Cornely OA, Bottiger BW, Dusse F, Eichenauer DA, Fuchs $F$, et al. COVID-19 associated pulmonary aspergillosis. Mycoses 2020 Jun;63(6):528-534.

14. Song G, Liang G, Liu W. Fungal co-infections associated with global COVID-19 pandemic: a clinical and diagnostic perspective from China. Springer Nature BV 2020;185:599. 606.

15. Gangneux JP, Bougnoux ME, Dannaoui E, Cornet M, Zahar JR. Invasive fungal diseases during COVID-19: we should be prepared. J Mycol Med 2020,30:100971.

16. Mehta S, Pandey A. Rhino-orbital mucormycosis associated with COVID-19. Cureus 2020;12(9):e10726.

17. Werthman-Ehrenreich A. Mucormycosis with orbital compartment syndrome in a patient with COVID-19. Am J Emerg Med 2021;42:264.e5-264.e8.

18. Mekonen ZK. Acute Invasive rhino-orbital mucormycosis in a patient with COVID-19-associated acute respiratory distress syndrome. Ophthalmic Plast Reconstr Surg 2020;20.

19. Spellberg B, Edwards J, Ibrahim A. Novel perspectives on mucormycosis: pathophysiology, presentation, and management. Clin Microbiol Rev 2005; 18(3):556-69.

20. Chamilos G, Lewis RE, Kontoyiannis DP. Delaying amphotericin $B$-based frontline therapy significantly increases mortality among patients with hematologic malignancy who have zygomycosis. Clin Infect Dis 2008;47:503-9.

\section{Yazıșma Adresi/Address for Correspondence}

Dr. Mustafa Serhat SAHINOĞLU

Mersin Üniversitesi Tip Fakültesi,

İnfeksiyon Hastalıkları ve

Klinik Mikrobiyoloji Anabilim Dalı,

Mersin-Türkiye

E-posta: srhtsah@hotmail.com 